\title{
PERSPECTIVES
}

\author{
Peter Tufano
}

\section{Training Leaders to Win Wars and Forge Peace: Lessons from History}

\begin{abstract}
Leaders of business schools and other educational institutions have enjoyed decades of stability. Today, we confront a set of systemic global challenges, including a pandemic, severe economic weakness, heightened inequality, racial injustice, and a climate emergency. Taken together, these challenges redefine the environment in which we operate-and offer us an opportunity to reimagine our organizations. We can learn about how to deal with this level of upheaval by studying how leading U.S. business schools responded to World War II. All shrank as students and faculty were drafted, most innovated in fairly traditional ways while still maintaining existing activities alongside of war-time innovations, and some pushed forward long-standing institutional change. One school choose a different path, shutting all peacetime programs as it fully committed not only to helping win a global war but, just as importantly, to forging a lasting peace-the long-term economic prosperity that followed the war. The lessons we can draw from academic leaders from nearly eighty years ago are apt today.
\end{abstract}

$\mathrm{I}$

magine, as a business school leader, finding that students are suddenly either unable or unwilling to study at your school. Your faculty likewise are unwilling or unable to teach. While a few sectors of the economy are thriving, many others are languishing. There is a great deal of global upheaval and it is difficult to travel internationally.

I acknowledge the helpful comments of Colin Mayer (Dean, University of Oxford's Said Business School, 2006-2011), Nitin Nohria (Dean, Harvard Business School, 2010-2020), Jordi Canals (Dean, IESE, 2001-2016), Robert Bruner (Dean, University of Virginia's Darden School of Business, 2005-2015), Andrew Pettigrew (Dean, University of Bath's School of Management 2003-2008), Ann Harrison (Dean, Berkeley Haas, 2019-present), Gay Haskins, Adrien Jean-Guy Passant, Sandra Epstein, Geoff Jones, and especially Jeffrey Cruikshank.

Business History Review 94 (Winter 2020): 807-833. doi:10.1017/Sooo7680520000768 (C) 2021 The President and Fellows of Harvard College. ISSN 0007-6805; 2044-768X (Web). 
Your finances are turning from black to red. You do not know how long the situation will last. While some think this will be a temporary phenomenon, you believe that the future may look dramatically different from the past-but you are not certain how or when.

This is not a description of COVID-19, which threatens lives and livelihoods, creating economic, humanitarian, civil liberty, ethical, and political crises while also exposing wounds in our societies. Rather, this is a description of the world faced by leaders of the relatively new business school sector in the United States at the outbreak of World War II. The world around them shifted abruptly and they found themselves entering a war even while staying at home. A few years later, they found themselves being asked to help fashion a postwar peacetime economy, mindful of the failure of the post-World War I recovery that had contributed to a global depression and repeated war.

Like our earlier counterparts, our generation of business school leaders is entering an unprecedented period-moving abruptly from peacetime to wartime footings, doing our part to win wars against the current COVID-19 pandemic and intertwined economic and humanitarian crises, facing urgent demands for racial justice, and confronting the existential threat of climate change. Some resist the metaphor of wartime. However, a closer examination of history and the present day shows that in both, educators like us are called upon to not only do our part on the home front to confront immediate structural and systemic challenges, but also to help fashion a new "peace"-a stronger, more just, more planetary-aware future post-COVID.

Like our predecessors eight decades ago, we are being called to develop leaders who must confront threats to life as we know it. The lessons of eighty years ago-before, during, and after World War IIare relevant today as we make this rapid and unpracticed transition. Both then and now, business schools need to transform dramatically first to win the war-and then to win the peace. In the context of COVID-19, the current war is against a virus as well as the associated economic, political, and social aftershocks; the peace will be to build a stronger, more cohesive, and more just economies and societies coming out of this emergency. In the context of racial justice, the war is to directly address the most obvious manifestations of systemic racism; the peace is to build a more truly just society. In the climate space, the war is to reduce our wanton destruction of the planet; the peace requires us to build economies and societies with sustainable carbon budgets. In each case, leadership is essential as we transition from winning a war to fashioning a lasting peace.

This piece was written for leaders of business schools and of higher education more generally, but it may be enlightening to leaders further 
afield. As a business school dean and amateur business historian, I have studied the World War II period and spoken about it at a few conferences of my peers. It never seemed relevant to my counterparts, who were naturally preoccupied with the daily challenges of ensuring excellent education and research, assembling classes, raising money, and climbing up the rankings. Yet, virtually overnight, we have all found ourselves squarely facing much larger issues. History may provide us with some useful lessons.

This article has two parts. In the first, we look at the responses at four leading U.S. business schools during World War II "in their own words," that is, using their histories published by their university presses. In the second, we examine more closely a fifth school that chose a different path. We use the five case studies to understand the opportunities to seize a global challenge to reinvent an organization. ${ }^{1}$

\section{Different Reactions to a Global Crisis in Philadelphia, Berkeley, Hanover, and Chicago}

Looking at the more recent COVID-19 or climate crises, we see organizations reacting in different ways. One reaction is denial, or an aggressive attempt to ignore the crisis and maintain the status quo. Despite the pandemic, some retail establishments conduct business "as usual" without masks or distancing; in the climate space, some deny the reality of climate change. A second reaction is reactive adaptation: making only adjustments that are absolutely necessary. We see this in most of the reactions to COVID by retail establishments. They comply with mask-wearing and social-distancing rules, and perhaps change their menus-say, reducing some variety or emphasizing grab-and-go or takeout. In the climate space, this might be akin to buying lowenergy light bulbs. A third reaction is to fundamentally alter your business model in light of the new situation. A restaurant that previously only served customers in person might add a produce shop on site or a "dark kitchen" only for takeout or commercial customers; to respond to the climate crisis, we might substantially curtail air travel or move from carbon fuels to renewables.

In the wake of World War II, the leading U.S. business schools mostly adopted reactive adaptation approaches in the sense that they largely kept some element of business as usual in place. They all acknowledged that students and faculty would enlist or be drafted and thus their programs would shrink. On the margin, they adjusted some elements of their curricula to emphasize skills like operations that might benefit

\footnotetext{
${ }^{1}$ For a complete understanding of the postwar period, see Mie Augier and James G. March, The Roots, Rituals, and Rhetoric of Change: North American Business Schools after the Second World War (Stanford, 2011).
} 
those manning factories or supplying war materials. At least two schools used the diversion of war to push peacetime institutional changes through their university processes. But some used the disruption of the war to rethink their programs and, in one case, fundamentally alter their approaches.

The approach adopted in this article is to use "modern" authorized histories to determine the role that wartime activities played in the arc of each school's development. Are the war years referenced extensively and seen as critical to the modern institution? For most schools, the answer is a resounding no. Tellingly, as schools recount their histories from the present, the war years hardly get any mention. For example, Columbia Business School, which was founded in 1916, published its centennial volume, A Century of Ideas, in 2016, highlighting the most important contributions of the preceding hundred years. ${ }^{2}$ World War II per se does not get more than a passing reference apart from a comment that operations became a more important topic. NYU Stern's history, NYU Stern School of Business: A Centennial Retrospective, written by dean emeritus Abraham Gitlow, does not even contain a reference to World War II in its subject index. ${ }^{3}$ A close reading of the book confirms the nearly absent consideration of the war years in the history of the 1900-founded School of Commerce. 4 While these schools existed during the war, these modern-day histories suggest that World War II played a minor role in creating the great modern schools they have become.

I acknowledge that this backward-looking approach may obscure the full impact of World War II on the schools, and therefore I contacted each of the current deans of the five schools profiled, asking for additional information that might not have been available in their official histories or current materials. I include their responses in the paper, which in some cases augment the written record.

For the first part of this analysis, I examine four of America's early business schools that acknowledge a wartime history: Wharton, founded in 1881, Berkeley (1889), Chicago (1898), and Tuck (1900). 5

\footnotetext{
${ }^{2}$ Brian Thomas, ed., A Century of Ideas (New York, 2016).

${ }^{3}$ Abraham L. Gitlow, NYU's Stern School of Business: A Centennial Retrospective (New York, 1995).

${ }^{4}$ In Gitlow's history, the only references to the war years include a note of the smaller-but still operating-classes during the war. For example, MBA enrollments fell from 1,196 in 1940/ 41 to 1,001, 656, 707, and 1,013 in the four following years, respectively. Gitlow, NYU's Stern, 120.

${ }^{5}$ Other early American business schools include those at Northwestern University (School of Commerce in 1908, now Kellogg); Harvard Business School (1908); MIT (originally Engineering Administration in 1914, now Sloan); Babson College (1919); Indiana University (School of Commerce and Finance in 1920, now Kelley); and Stanford Graduate School of Business (1925). The U.K. business school sector and many of the modern elite European business schools were postwar innovations: for example, Insead (1957), IESE (1958), London Business
} 
These four elite institutions, whose founding predated the twentieth century, had lived through World War I and the Depression and were fairly mature, well-regarded schools at the onset of World War II. I focus on U.S. business schools not because they were the earliest but rather because while the United States was at war, battles were not being fought "at home" and hence academic leadership had more flexibility in determining how they might operate. In comparison, continental European schools, including the earliest business school, ESCP (founded in 1819 as the Special School of Commerce and Industry) had many more externally enforced constraints. Adrien Jean-Guy Passant, who chronicles the history of ESCP Business School in A l'origine des écoles de commerce, shows that during the war it experienced physical relocation, Vichy-ordered temporary closures, suppression of speech, bans on Jewish teachers, and more, though it continued to operate. $^{6}$

Wharton: Hunkering down during the war years. At Wharton, America's first business school, World War II seems to have played a minor role-an externally imposed pause. The official Wharton history, The Pragmatic Imagination: A History of the Wharton School, 18811981 , written by Stephen A. Sass, devotes only about 3 pages out of 342 to the war. The following passage seems to capture nearly the entire impact of World War II on the school: "The nation was busily preparing itself for war. Professors, as well, left the school's employ and found their way into a great variety of useful positions with the federal government. Wharton, in fact, all but adjourned for the duration of the conflict, and the number of its full-time faculty, which had recently totaled 165 , fell to 39 by $1944 . " 7$ The account then identifies two professors, George W. Taylor and Simon Kuznets, who worked with the government during the war. Taylor chaired the War Labor Board, which regulated wages in all industries, and Kuznets was associate director of the Bureau of Planning and Statistics at the War Production Board. Both made substantial individual contributions to the war effort. While campus life at Wharton was reduced, it seemed to carry on in a more or less traditional way during the war: "The school continued to train large numbers of students in traditional business subjects, such as accounting, finance, and insurance, and professors and graduates in

\footnotetext{
School (1964), Cambridge Judge Business School (1991), and Said Business School-Oxford University (1996).

${ }^{6}$ Adrien Jean-Guy Passant, A l'origine des écoles de commerce: ESCP Business School, la passion d'entreprendre (Paris, 2020).

${ }^{7}$ Stephen A. Sass, The Pragmatic Imagination: A History of the Wharton School, 18811981 (Philadelphia, 1982), 226.
} 
these areas also found themselves drafted into responsible positions during the war." ${ }^{\circ}$ In short, while Wharton contributed to the war effort, it appears to have done so through the individual efforts of faculty and alumni, rather than institutionally. The war was a pause, not an inflection point. In the immediate postwar period, the school picked up from before, as Sass summarizes: "But as the worlds of affairs and ideas rushed headlong into the future, the Wharton School resumed its prewar routines."9

Berkeley: Creating an MBA program and business school in the midst of the war. The University of California College of Commerce, founded in 1898 and now known as Haas Business School at the University of California at Berkeley, operated an undergraduate commerce program at the time the war broke out. In the 396-page history Business at Berkeley: A History of the Haas School of Business, by Sandra Epstein, World War II per se is mentioned in just a few paragraphs and seems not central to the history of the school. ${ }^{10}$

With the draft, the number of undergraduate commerce students dropped by about a third, to about one thousand. The broader University of California system adopted various changes, including pass-fail grades, some refinements in curriculum, and rule changes permitting students to complete a four-year undergraduate program in two years and eight months. At the university and the College of Commerce, Epstein notes, there was little change in the curriculum:

The general curriculum did not change, but some courses were added and others received stronger emphasis. For commerce studies, a minor adjustment was made in the area of operations management. What had been a minor area saw new courses added in response to the defense needs of producing essential materials and supplies. Several senior business students joined a Department of Mechanical Engineering course in time and motion study; likewise engineering students took technical courses like Production Management and Control in the College of Commerce. ${ }^{11}$

Another paragraph describes various wartime collaborations. The College of Commerce joined together with colleagues in mechanical engineering and economics to deliver the federally financed Engineering, Science, and Management War Training (ESMWT) program to speed up training for war work. The university also cooperated with the U.S.

\footnotetext{
${ }^{8}$ Sass, 228.

${ }^{9}$ Sass, 233 .

${ }^{10}$ Sandra Epstein, Business at Berkeley: A History of the Haas School of Business (Berkeley, 2015).

${ }^{11}$ Epstein, 149.
} 
Office of Education by providing specialized war-related training courses. ${ }^{12}$

While Epstein's account does not present the war efforts as central to the modern history of the school, the war years were. In the middle of the war, the priorities of Berkeley's new dean were to split its economics and business administration activities, set up the latter as a "school" rather than a "college," establish the "Master of Business Administration" graduate degree, and set up joint curriculum with engineering and other departments. ${ }^{13}$ Indeed, in the written history of the school, the most important activity during the war, receiving far more attention in the volume than war-related activities, was the creation of the School of Business Administration in 1943 and awarding of the MBA degree in 1944. The issues seem contemporary: wanting greater autonomy within the university, finding a positioning ("business" versus "commerce") that had a better "public relations perspective," gaining budget and space for the new school, having control over faculty hiring, and "winning long-sought independence from the Economics Department." The war provided a backdrop for the move:

Having gained departmental status, the groundwork was now laid for conversion of the College to a School, and Dean [Ewald T.] Grether urged that the action be taken quickly. Drawing upon historical precedent, he feared that if the new organizational plan was not adopted, it might again be lost among postwar enrollment pressures, precisely what had occurred after World War I. He also pointed out that failures to adopt those 1915 and 1921 proposals to establish a "school" of business had left the University a quarter of a century behind the times... . The timing was propitious since the wartime campus enrollment was smaller. ${ }^{14}$

The leadership at Berkeley used the wartime crisis to forge meaningful institutional change within the University. As the war raged in Europe, North Africa, and Asia, its battles were closer to home. It is as if the war was a diversion that permitted long-standing peacetime institutional changes to move forward.

These war-time innovations defined the modern Haas, as Ann Harrison, the current dean, notes:

The Berkeley Haas decision to launch an MBA degree when as the leading US public university we are constantly hit by fiscal crises and state mandates was nothing short of extraordinary. I am amazed at how Berkeley keeps tuition down, continues to accept more students,

\footnotetext{
${ }^{12}$ Epstein, 150.

${ }^{13}$ Epstein, 152.

${ }^{14}$ Epstein, 158, 159.
} 


\section{Peter Tufano / 814}

and truly acts as an engine of social mobility on a tight budget. We simply don't have the option to stop revenue generating activities with an endowment which is a small fraction of our competitors. ${ }^{15}$

The chronicler of Haas's history, Sandra Epstein, wrote to lay out some additional impacts of the War that were not included in her centennial volume:

While the Haas history does not devote as much space to World War Il activities, it nonetheless was a very productive period at Berkeley. In addition to becoming a school and introducing the MBA, the business program introduced a number of new programs and courses. It was a time of the founding of the organized research unit (ORU) including Bureau of Business and Economic Research, which led after the war to adding Labor Studies, Industrial Relations, and Real Estate. New interdisciplinary courses which contributed to the war effort were added, particularly bringing together business and engineering and a whole new course group in Foreign Trade and Government Foreign Service. Of special note was the introduction following the war of the first course that would develop into the outstanding group in business and public policy. ${ }^{16}$

These activities parallel the HBS narrative, described in more detail later in this article. Clearly, the war years were central to the formation of the modern Berkeley Haas, not only due to its war efforts, but more importantly for the intra-university negotiations, led by an incoming dean, that created a modern business school.

Tuck: Mobilizing war efforts alongside traditional business education. In 1900, the first graduate school of business, the Amos Tuck School of Administration and Finance (now the Tuck School of Business) at Dartmouth College, opened. A collaboration between the president of Dartmouth College, William Jewett Tucker, and his former college roommate and financier, Edward Tuck, the school took a very different path than other early schools. From the outset it saw business education as graduate education, either for men with college degrees or for Dartmouth undergraduates who had successfully completed their first three years of college. It was conceived as a program to marry liberal arts with economic and finance education. Tuck conferred the first American advanced degree in business, a Master of Commercial Science. ${ }^{17}$

\footnotetext{
${ }^{15}$ Ann Harrison, private correspondence with author, 2020.

${ }^{16}$ Sandra Epstein, private correspondence with author, 2020.

${ }^{17}$ For a history of the early years of the school, see Wayne G. Broehl, Tuck and Tucker: The Origin of the Graduate Business School (Hanover, NH, 1999). This history stops before the war years.
} 
The Tuck School, from its founding model through its deep connection with the college via its $3^{+2}$ model of undergraduate education leading to postgraduate business training, took a joined-up approach when the war broke out. President Ernest Martin Hopkins laid out two goals for the college and its three professional schools: to maintain the liberal arts curriculum for civilian students and to support the war effort. ${ }^{18}$ In effect, two parallel sets of activities took place at Dartmouth: military and civilian with the latter gaining greater emphasis during the war:

Adjusting to the consequent shortage of college-educated commissioned officers, the U.S. Navy developed a way to combine college education with military service: the Naval Indoctrination Training School and the V-12 Naval Training Program. Dartmouth became host to the largest of the Navy's V-12 units. On July 1, 1943, some 2,000 enlisted men and an officer staff came "on board" at the College, including 300 students from Dartmouth and 74 from Thayer School. The College and its three professional schools accelerated their curricula and shifted to three-term, year-round operation. Fraternities closed, Winter Carnival was cancelled, the Daily Dartmouth ceased publication and rationing was put in place. Civilian students were outnumbered three to one on campus. Run on military time, with reveille at 6 am and taps at $10 \mathrm{pm}$, Dartmouth operated like a naval base for the duration of the war. ${ }^{19}$

During the war, Tuck created the Tuck-Thayer program, combining forces with the Thayer School of Engineering at Dartmouth. This collaboration between business and engineering was a direct response to war needs. In 1942-a year before Berkeley moved in the same directionthe School changed its name to the Amos Tuck School of Business Administration.

Today, Dartmouth places considerable emphasis on its activities during the war, devoting a special website, with letters and oral histories from veterans, a film, pieces from alumni magazines, and more information online. Virtually all of this material relates to the undergraduate and alumni experience. Little refers specifically to Tuck, presumably because its postgraduate model was severely constrained when undergraduates completed their program on accelerated schedules and did not continue on to get the MCS degree. Nevertheless, the war provided the impetus for the modern business school at

\footnotetext{
18 "Dartmouth during World War Two," Rauner Special Collections Library, Dartmouth College, accessed 8 Dec. 2020, https://www.dartmouth.edu/library/rauner/archives/oral_history/worldwar2/history.html.

19 "Dartmouth during World War Two"; for additional detail, see Jennifer Seaton, "Engineered for Service," Dartmouth Engineer Magazine, Winter 2008, https://engineering.dartmouth.edu/magazine/engineered-for-service.
} 
Dartmouth and the long-standing Tuck-Thayer collaboration that persists more than 75 years later.

Chicago: Innovating for war and peace. World War II was consequential for the University of Chicago, as captured in John W. Boyer's volume, The University of Chicago: A History. In the years prior to the war, university president Robert M. Hutchins was engaged in a massive effort to reform undergraduate education in Chicago. Hutchins apparently timed one of his major long-standing moves in conjunction with the start of the war: "early in January 1942, in the aftermath of the American declarations of war on Japan and on Germany, Hutchins suddenly and with considerable drama proposed that the BA degree be transferred from the jurisdiction of the divisions to the College and that it be conferred upon completion of a four-year program in general education beginning with grade eleven, thus making it possible for Chicago to graduate eighteen- or nineteen-year-olds with BA degrees."20 This went along with a change in membership in the college faculty and disenfranchisement of a number of faculty members. These academic battles continued to be fought in Chicago throughout the war years. The implication of this university-wide innovation was to "effectively eliminate the departments and specializations from the undergraduate curriculum," including the undergraduate business program, to delineate between the undergraduate Chicago experience and the "specialized learning offered and the divisions and the professional schools." ${ }^{21}$ While this monumentous decision was taken outside of the business school, it transformed Chicago's business school into a graduate school, like Tuck.

President Hutchins opposed the war and promoted isolationism; however, with the attack on Pearl Harbor, the university took on the war effort, albeit with a characteristic Chicago approach:

The effects of total war were soon seen throughout the campus. The University agreed to host a variety of military training programs, and by 1942 all available dormitory space had been consigned to military programs.... However, the military training programs of 194244 were different from the [World War I] 1918 SATC [Student Army Training Corps] model, which Hutchins and other university leaders despised. In June 1940 Hutchins had joined with six other midwestern university presidents to write a memorandum outlining the appropriate roles of the university in time of war. The presidents affirmed that the universities should do what they could do bestnamely, provide substantive knowledge-based training programsand not become substitute army encampments. ${ }^{22}$

\footnotetext{
${ }^{20}$ John W. Boyer, The University of Chicago: A History (Chicago, 2015), 253.

${ }^{21}$ Boyer, 254-55.

${ }^{22}$ Boyer, 301, 302.
} 
Other wartime commitments at Chicago included special training for soldiers and sailors on medical hygiene, optics, electronics, nursing supervision, and Japanese, creating a campus that Hutchins called "an instrumentality of total war." 23 Perhaps the most far reaching wartime initiative was the recruitment of refugee scholars from Europe, including Enrico Fermi and Hans Morgenthau, as well as the "Met Lab," which was a joint government-university project connected with the highly secretive atomic bomb project. ${ }^{24}$

Chicago's College of Commerce and Politics had been set up in 1898, only eight years after the founding of the university. ${ }^{25}$ Remarking on the founding of the college, the University of Chicago's first president, William Rainey Harper, noted its academic character:

When it was first proposed by Head Professor Laughlin that the university should organize work in a line of subjects more closely with the great fields of commerce and politics, it was still a question whether that work should take the form of a professional school or be organized as regular college work. After long debate in the faculties and senate of the university, it was decided that the work should be organized as a college and administered as such. Herein lies the great difference between the work as thus presented in the University of Chicago and certain work of perhaps a similar character undertaken elsewhere. ${ }^{26}$

Following this direction, Chicago established the "world's first $\mathrm{PhD}$ program in business" in 1920, to advance the "scientific study of business," and was renamed the School of Business in 1932. ${ }^{27}$ At the time the war broke out, it offered undergraduate, academic master's, MBA (starting in 1935), and doctoral courses.

As noted above, the undergraduate programs were shut in 1942, but during the war, an important and long-lasting innovation was introduced at the School of Business. In retelling its history, Chicago Booth emphasizes the role of the war-in particular, the wartime impetus to create the first Executive MBA (EMBA) program in 1943. This parttime program was explicitly seen as a way to address the wartime

\footnotetext{
${ }^{23}$ Boyer, 303 .

${ }^{24}$ Boyer, 305 .

${ }^{25}$ For a near contemporaneous account of business education globally in 1900, see Frederick Hooper and James Graham, Commercial Education at Home and Abroad (London, 1901), https://ia800206.us.archive.org/2/items/commercialeducaoocoungoog/commercialeducaoocoungoog.pdf. It is interesting to note the leading role played by European schools, as well as the distinctions drawn between commercial education and graduate business studies.

${ }^{26}$ Quoted in Hooper and Graham, 141.

27 "Innovating-Always," Chicago Booth website, accessed 3 Dec. 2020, https://www.chicagobooth.edu/why-booth/innovation-history.
} 
shortage of trained managers. While these first EMBA students' profiles were quite different from "traditional" students, the content of their program and faculty were the same as for the full-time counterparts:

The 52 students comprising the world's first Executive MBA class met two nights per week in downtown Chicago. Many of the students came from iconic Chicago companies such as Marshall Field's, Commonwealth Edison, Illinois Bell Telephone, Walgreen Co., Chicago Tribune, and Spiegel. Some worked at local manufacturing companies that made gears, freight cars, conveyor belts and machinery. They were accountants, plant supervisors, engineers, production managers, purchasing agents and even one librarian. In the early years, students were typically in their 40 os or early 50s, with decades of work experience but little formal business education. They attended classes taught by the same faculty as students in the Full-Time MBA Program, unusual for part-time programs of that era. ${ }^{28}$

The EMBA program at Chicago has remained an important part of the university's offerings, and Chicago Booth's current website celebrates the program's wartime origins. Like the Tuck-Thayer collaboration, Chicago's EMBA innovation was explicitly war-related, but subsequently proved to be a long-lived model.

These sketches, reflecting the briefest of mentions of the war in the modern histories of these schools, demonstrate a range of ways that these American business schools dealt with the challenges of a global conflagration. While all come from contemporaneous histories, they suggest that war had a range of impacts on these four schools: for one, it brought about little long-term impact on the "modern" school that went back to its prewar routines (Wharton); the diversion of the wartime years was exploited to create a traditional business school enterprise while also sowing seeds for future initiatives (Berkeley); temporary wartime efforts proceeded alongside a parallel but reduced set of traditional peacetime programs but also created a long-lived collaboration (Tuck); and beyond temporary wartime and traditional programs, some innovation aimed at meeting war-time needs created lasting and material programmatic change (Chicago). While the data on their wartime activities is limited, it is clear the period from 1941-1945 was one that led to substantial innovation at most schools, some explicitly aimed at the war and others positioning the schools for peacetime

\footnotetext{
28 "How the World's First Executive MBA Program Changed Business Education," Chicago Booth Media Relations and Communications, 16 Feb. 2018, https://news.chicagobooth.edu/ newsroom/how-worlds-first-executive-mba-program-changed-business-education.
} 
A fifth example completes this pattern: A school that voluntarily abandoned all of its peacetime programs, devoted all of its attention to training soldiers and those left at home to run factories, and decided at the end of the war, by a unanimous vote of the faculty, to not return to offering its prewar peacetime program. This school, Harvard Business School (HBS), serves as the final example as we consider how "temporary" crises can forge lasting institutional change.

\section{A Fifth Approach: Harvard Business School in World War II}

While World War II's impact at Wharton, Berkeley, Tuck, and Chicago was varied, a more extreme institutional reaction to the war occurred on Soldiers Field in Boston. Jeff Cruikshank extensively documented Harvard Business School's experience in the 1940 os in his official history, A Delicate Experiment. ${ }^{29}$ In contrast to the other histories cited, Cruikshank devotes 61 pages in the 285-page volume to the wartime years; indeed, a chapter titled "Almost a Complete Break" presents these years as a defining period in the history of the school. Below I provide some of the details of this history, which demonstrated a willingness to go "all in" to engage in waging war and building peace. This history suggests five lessons that I believe are relevant to current battles with other systemic challenges, be they COVID-19, a climate emergency, economic crises, or racial, national, and international divisions: (1) When is a war our war? Resisting the initial threat is normal. (2) What is our purpose (or purposes)? Missions evolve over time as we move from waging a war to building a peace. (3) Can we actually do that? Innovation is possible in war, perhaps for a while. (4) Who decides? Academic decision making differs in wartime and peacetime. (5) The upside: "Whatever it takes" can liberate us and lead to meaningful organizational innovation.

Some of these lessons can also be seen in the other four examples but are called out in greater detail in the history of Harvard Business School. To be clear, this is not a statement about one school's exceptionalism, but rather an example of how an institution can completely adopt an external mission and in so doing, transform itself.

When is a war our war? Resisting threats is normal. Even with a formal declaration of war, it's not unusual is to try to maintain business as usual for as long as possible, worrying about everyday issues before accepting that everything has changed. In short, for a while, $a$ war is not yet our war. This was true eighty years ago. Until December 1941,

\footnotetext{
${ }^{29}$ Jeffrey L. Cruikshank, A Delicate Experiment: The Harvard Business School, 19o81945 (Boston, 1987).
} 
when President Roosevelt entered the fray in response to the bombing of Pearl Harbor, war had been raging for three years in Europe. The Anschluss invasion of Austria occurred in March 1938. Germany invaded Poland, and France and Britain declared war, in September 1939. Germany invaded and took over Denmark, Norway, the Netherlands, Belgium, and France between April and June 1940. The Battle of Britain, where the underpowered British Air Force held off the German Luftwaffe, took place in July 1940. The Blitz, during which the United Kingdom suffered under nightly bombings that dropped 41,000 tons of bombs, continued in 1940 and 1941. The Axis Alliance of Germany, Italy, and Japan was formed in September 1940. The Axis powers attacked Russia in June 1941.

None of this was unknown in the United States: there was $a$ war, just not our war. The Chicago history, where President Hutchins opposed the war and promoted isolationism actively, demonstrated a not uncommon distancing from the global crisis. This distancing was not unique to Chicago: the HBS alumni magazine published an article in 1941 by a French HBS alumnus, entitled "Blitzkrieg Tactics: A Warning to the United States," that presciently noted, "The world is growing smaller [and] isolation is an illusion." 30 Some in America even embraced the Nazi cause. An event organized in 1939 by the German American Bund in Madison Square Garden in New York City, chillingly portrayed in the documentary film A Night at the Garden by Marshall Curry, made clear the Nazis' intent and the support of twenty thousand New Yorkers in attendance. ${ }^{31}$ Yet, at the same time, the war was resisted by many, such as "pacifists, communists, fascist sympathizers, and members of the isolationist America First Committee."32

Prior to Pearl Harbor, business as usual was the practice at Harvard Business School. Wallace Donham-who served as dean of HBS from 1919 to 1942-sought to not repeat the school's experience in World War I, when it lost too many men from the MBA program, lost faculty to the draft, and ran a large financial deficit. While "doing its bit," the school would maintain business as usual as much as possible. Even so, in the months even before America entered the war, the U.S. government and HBS took tentative steps to prepare. HBS established a Reserve Officers' Training Course (ROTC) at HBS in April 1941; this did not alter the MBA training but simply added extra courses in defense mobilization. Two months later, n June 1941, the Naval Supply Corps School physically co-located on Soldiers Field Road, sharing the

\footnotetext{
${ }^{30}$ Cruikshank, Delicate Experiment, 218.

${ }^{31}$ The film can be seen online, https://anightatthegarden.com/.

${ }^{32}$ Cruikshank, Delicate Experiment, 219, 220.
} 
campus alongside the traditional MBA program, "work[ing] more in proximity with each other than together." 33 "We do not teach these officers," [HBS] Dean [Donald] David noted, "but we do house and feed them, and we feel fortunate in having this group of outstanding officers living and associating with us here." ${ }^{34}$ Co-location was step one in a pattern of engagement, consistent with the Tuck and Chicago experiences.

Adaptation was step two, and in February 1942, HBS admitted the Navy Supply Corps Midshipman Officer School but merely bolted additional curriculum onto the existing first year of the MBA for these students. Later in 1942, the School moved even further, launching the Army-Air Force Statistical School (Stat School), which drew HBS faculty out of the MBA classroom to teach soldiers.

The ultimate rejection of business as usual transpired a year after Pearl Harbor, in December 1942, when the faculty voted to discontinue all non-wartime programs-to shut its MBA program, even while Berkeley was working to create one. By 1943, all activities at HBS were devoted to winning the war, training the officers who would lead overseas and the civilians who would lead the factories at home, while also conducting war-related research on campus.

While HBS ultimately put all of its resources into winning the war, doing so was not an immediate or easy decision. Reading between the lines, business-as-usual concerns-budgets, student numbers, and faculty sufficiency-were pitted against an emerging and much larger external mission. This sounds very modern. Today, in the face of the trio of health, economic, and humanitarian crises brought about by the COVID pandemic, business school leaders are mostly focused on trying to maintain business as usual: moving classes online, extending deadlines for applications, dealing with student dissatisfaction, trying to keep executive education business afloat, and worrying about the losses that will we all face with high fixed-cost bases. We are only beginning to turn our attention to winning the war-that is, fighting the pandemic and using the full strength of business and business schools to soften the blow that COVID-19 will have on individuals, families, and organizations from public-health, business, and humanitarian perspectives.

But our reaction to COVID is still quicker than our response to the slower, more treacherous wars we need to win against racial injustice and planetary destruction, both of which have seemed remote-like the war in Europe, even though the evidence is clear. While COVID

\footnotetext{
${ }^{33}$ Cruikshank, 226.

${ }^{34}$ Cruikshank, 226.
} 
compels a response, we have largely not had to fully deal with the issues of racial or climate justice. These are faraway wars, not yet "ours." We are not the first in history to try to protect and distance our organizations from external crises. As the histories of the other successful business schools show, this strategy is common. But the HBS example shows that leaders can make these large external issues their own and bring reluctant organizations along.

What is our purpose (or purposes)? Life in wartime requires flexibility. The power and resilience of a university comes from the huge breadth of energy pursued by individuals organized by an intellectual "invisible hand." As a result, universities, committed to academic freedom, often tend to have their "purposes" implicitly defined as the collection of the goals of their faculties and individual academics. Yet in wartime, individual purpose needs to give way to collective purpose. This sequence was evident at HBS over the first part of the war.

In late 1941 and throughout much of 1942, the purpose of HBS was unclear. One camp seemed to be trying to continue business as usual as much as possible. This allowed the various individual agendas to continue to be advanced, be they research or teaching. Yet by the end of 1942, when the faculty voted to close all peacetime programs, it was clear that the school had adopted a collective mission: "Win the war." This manifested itself first in a series of programs to teach officers and soon thereafter in a series of programs to teach left-behind business executives.

However, as the war wore on and the tide was turning, the school's collective purpose shifted dramatically once again: "Win the peace." When the war was won, the cessation of wartime production and the large amount of surplus war material meant that the economy could easily go into a tailspin just as the troops returned home looking for jobs, as had happened in the wake of World War I. The clear imperative was to create a stable and growing economy. Dean Donald David acknowledged this in 1945: "Surely the School's wartime record would soon seem incidental and would be quickly forgotten if our efforts on behalf of the men who have won this were any less determined than our efforts in the officer-training program." 35

This task-winning the peace-has defined the business school sector since World War II: to create prosperity through business. On both sides of the Atlantic, business schools of the late 1940s through the 1960 s saw their raison d'etre as supporting businesses to grow, which would thereby create products for consumers to buy and jobs for workers-and, starting in the 1980s, increased value for

\footnotetext{
${ }^{35}$ Cruikshank, 275.
} 
shareholders. These evolving agendas were and continue to be the essence of "winning the peace" for business schools. They remain the mantra today. At alumni reunions across the world, deans take great pride in announcing the number of ventures, market capitalizations, and jobs created by their alumni.

Having lived in peacetime for decades, we have not had to deeply question our purpose as business schools. We have mostly adopted one-size-fits-all strategies, emphasizing rigorous academic research and maximizing the salaries of our graduates. We bow to external rankings that prioritize ever higher alumni salaries, we are pressured by faculty demands for ever higher faculty salaries, and the battle for students leads to a need for greater fundraising to offer more scholarships and to build ever more beautiful campuses.

But higher alumni or faculty salaries and beautiful campuses will not win wars. As we confront the specter of a pandemic that can ravage communities and economies, racial and national divides that can explode, and the threat of planetary extinction, what are our purposes as business schools? What is our role in winning these wars? And how will we transition to winning the next peace-first, creating shared prosperity when we emerge from our forced social distancing; then, creating a model for a sustainable and just economy? We must be prepared to clearly articulate our purpose and then to recognize that it will almost surely change as we move from winning a war to fashioning a lasting peace.

Can we actually do that? The "temporary suppression of academic perfectionism" and attendant innovation. For the University of Chicago, the EMBA program was a signature wartime achievement, even though its curriculum was identical to that of the full-time MBA. For Dartmouth, the Tuck-Thayer collaboration, while small during the war, continued to flourish for decades. For Berkeley and Tuck, crucial wartime innovations were the creation of MBA programs and the moniker of "Business School." Beyond this, curricular innovation in the business school sector, apart from an increased emphasis on operations, seemed minimal. Innovation in students, apart from servicemen brought for training and Chicago's EMBA, also seemed minimal. The story at HBS seems markedly different. There, war was a powerful stimulus for bringing together previously disparate groups and fostering innovation that might have been unthinkable in peacetime. These innovations were the result of what one junior professor at the time, Dan T. Smith, called "the temporary repression of traditional academic perfectionism." 36 While peacetime has the luxury of slow, tested, and

\footnotetext{
${ }^{36}$ Cruikshank, 243.
} 
careful change, wartime does not. This partial "temporary repression of perfectionism" laid the grounds for modern business education, even though not all of these innovations persisted in the seventy-five years of subsequent peacetime.

Accepting new types of students. Before the war, HBS MBAs (like those at other schools) were young, white businessmen. But those going off to war and risking their lives were much younger than traditional MBAs, and the people left to operate the factories were much older than traditional MBAs. Neither had been welcome on Soldiers Field before 1941, but during the war both became central to the HBS wartime mission, one temporarily and the other permanently.

Winning the war in Europe and Asia required masses of young people, who were the core of the undergraduate programs at Berkeley and Wharton and the MCS program at Dartmouth. Dean David of Harvard reluctantly acknowledged the need to begin to cater to younger students: "It now seems probable that we shall soon be receiving trainees 18 or 19 years old. Thus, for the first time we have been asked by the Armed Services to give advanced professional training to men who we should normally feel were not sufficiently mature to handle this work effectively... . [We must] mature the judgment of these officers . . . to place greater stress on the matter of human relations." 37 David noted that this would require smaller classes and greater student-faculty interaction-both of which collided with the fundamental economic model of the school developed in the decades since World War I. After the war, HBS would not welcome young people to Soldiers Field again until 2011, with the opening of the i-Lab (a facility for entrepreneurs from across the university). Small classes did not become the norm. However, the emphasis on human relations-which began in the 1930s but flourished during the war-was longer lived.

Also long lived was the wartime innovation of bringing older students to campus. In blunt terms, the prevailing sentiment at HBS before the war was that older executives were not clever enough to learn or were too rigid or set in their ways to learn. One director of an airplane division described them as "dummkopfs." 38 But someone needed to run the factories. HBS reluctantly embraced this idea and at first did not know how to do it: "Throughout the fall of 1942, the School had assumed that Harvard's name, combined with the widespread desire to contribute to the war effort, would be sufficient to populate the course [for training factory executives.] In fact, only a dozen inquiries had been received by early December. . . .'We have to do

\footnotetext{
${ }^{37}$ Cruikshank, 267.

${ }^{38}$ Cruikshank, 236.
} 
something, Gene,' the Dean told [Eugene Zuckert, an administrator who was leading this effort] in no uncertain terms. 'I think you need to get your ass out in industry." 39 The result, after some missteps, was a formula that survives today and defines executive education: focusing on executives at mid- and senior levels, both nominated by their employers and self-sponsored. What seems obvious today was deeply resisted in its time. The program was initially derided on campus as the "retread" program but over time was acknowledged as critical. According to Cruikshank, "the School's novel concept of executive retraining seemed to be proving itself. Perhaps most important, it was clear that men and women twenty or thirty years out of school could still learn-a dubious assertion, to many, before the retread program." 40 This notion of training for mid- and senior-level executives who would quickly return to manage their organizations survives to this day in programs across many business schools in the form of Executive Education. Chicago's wartime EMBA program followed the same model, but in keeping with the school's academic bent, the program was longer and offered a degree.

Finally, the war brought "the other" to the campus. HBS Dean David championed the Trade Union Fellowship that brought both women and Blacks to Soldiers Field. "No woman had previously attended class at the Business School. . . and relatively few blacks had received MBAs," Cruikshank notes. ${ }^{41}$ (In contrast, the Berkeley program enrolled women prior to the war. ${ }^{42}$ ) While social conventions were suspended in the war, they resumed afterward, and it was not until 1963 that women were enrolled in the full-time two-year MBA program.

New approaches to teaching and research. Descriptions of the wartime curriculum at Berkeley and Wharton suggest that changes were modest, but at Harvard the entire curriculum was revised. New types of students, needing new types of training, required that the school innovate. Before the war, as now, MBAs saw themselves as future CEOs and considered certain courses simply beneath their rank. In the war, however, these classes became core to the wartime curriculum in the Industrial Admin School, Stat School, and the Retread Program-and stayed that way after the war. Cruikshank writes that "many [prewar] first-year students saw themselves as destined for higher management positions.. . . Like Business Statistics, another required and generally derided first year course, Industrial Management seemed overly functional, and therefore perhaps beneath the

\footnotetext{
${ }^{39}$ Cruikshank, 233.

${ }^{40}$ Cruikshank, 257.

${ }^{41}$ Cruikshank, 269.

${ }^{42}$ Epstein, Business at Berkeley, 149.
} 
consideration of future captains of enterprise. 43 These topics, as well as human relations, mentioned above, became staples of not only the wartime curriculum but the subsequent peacetime curriculum as well, for decades. They were ultimately eased out of the HBS curriculum, with managerial economics (business statistics) dropped in 2001 and human relations in the late 1990 s, replaced by more finance and leadership requirements. It is interesting to note that the quantitative emphasis around logistics and statistics-central to the Stat School, which taught supply executives-was an early precursor to the current data analytics emphasis.

HBS had pioneered the application of "problem" and then "case" teaching in business. This was an innovation pressed upon the faculty by Donham in 1919, early in his tenure as dean, with a partner in marketing professor Melvin T. Copeland. This innovation was adopted as the school was gearing up to train returning war veterans from World War I. By the early 1940s, the case method seemed to have withstood the test of time, but in World War II the method was found partly inadequate. Finding traditional case studies stale and dated, HBS created "live cases [in which] actual data ... and a proposed plan of action was presented; students had to assess the feasibility of the plan based on the data ... to encourage initiative and imagination and to develop (or at least show the need for) initiative and judgment." 44 After the war, live cases were shelved in favor of traditional long-shelf-life and economically viable cases. However, there remained a sense of the importance of having timely material.

Research in World War II took on a new meaning, being directed to projects that would have a material impact on the winning of the war. We saw this in the Berkeley experience, where the organized research unit (ORU) including Bureau of Business and Economic Research, led in the postwar period to new work in Labor Studies, Industrial Relations, and Real Estate. At Harvard, there was a pointed concern for the utility of the work, such as the Air Research Program, carried out in conjunction with the aviation industry. In a spirit that characterizes the contemporary impact agenda, the program was evaluated in clear terms: "No matter how thorough a research study may be, it will be of little use if there is no interest in the subject on the part of the public or industry." 45 Research that crossed boundaries was also embraced, such as the HBS Fatigue Laboratory, done in collaboration with the Climatic Research Laboratory, combining science, physiology, and behavioral

\footnotetext{
${ }^{43}$ Cruikshank, Delicate Experiment, 230-31.

${ }^{44}$ Cruikshank, 244-45.

${ }^{45}$ Cruikshank, 255 .
} 
research to determine how airmen would fare in extreme weather conditions. While Wharton's professors left the school to join the government to do applied research during the War, Harvard's model was to bring very applied research inside the School. In both cases, professors made valuable contributions, with the difference perhaps reflecting a judgment of where it was appropriate to conduct highly "useful" research.

How does this map onto our current situation? In research, we continue to benefit from the adherence to rigorous academic perfectionism, but it can be applied more quickly to topical problems. For example, my colleagues in the Oxford labs have been credited with maintaining very tight research standards of randomized control trials to carefully analyze the benefits of vaccines and therepeutic drugs to battle COVID-19, but sped up testing. The contemporary movement toward "responsible research," or "credible knowledge that is ultimately useful for addressing problems important to business and society," moves in this direction. ${ }^{46}$ The Responsible Research in Business \& Management group holds out seven principles that would resonate with wartime or COVID-19 researchers: service to society, stakeholder involvement, impact on stakeholders, valuing both basic and applied contribution, valuing plurality and multidisciplinary collaboration, sound methodology, and broad dissemination. While not abandoning the rigor of scientific research that has little immediate value, the challenge at business schools is to produce useful and timely research that can also serve society.

Other parts of our academic enterprise might benefit from more liberal repression of traditional academic perfectionism-or at least tradition. In particular, the lesson of history suggests that teaching can become more flexible. The first reaction to COVID-19 has been to discuss how we teach-for example, online versus in person, synchronous versus asynchronous deliveries, and acceptable classroom densities. Yet in confronting a pandemic and economic crisis, racial divides, or a climate crisis, do we have to change whom we teach and what we teach?

As to whom we teach, the lesson of World War II was it would take young and old, men and women, of all races, to win a war. Some of these groups had historically been excluded from classrooms. Diverse groups like labor and management had to collaborate to fight against a mutual enemy. Indeed, the ultimate battle was not between countries but between the Allied and Axis powers, temporarily united supergroups of disparate countries. During World War II executives were welcomed at the University of Chicago, and the breadth of talent brought to HBS to win the war and peace was considerable. The analog today might be

46 "Executive Briefing," Responsible Research in Business \& Management website, accessed 16 Mar. 2020, https://rrbm.network/. 
around tolerating a wider range of approaches. We carefully separate schools of business, government, and public health, but a pandemic requires all of these skills and more. We draw lines between those schools and the sciences, but a climate emergency requires closer work between areas, as Dartmouth and Berkeley did in World War II when they joined forces with their engineering schools. Racial injustice will require us to be more inclusive in not only who is in our classrooms but also what we have the courage to discuss. Do we have the bravery to rip down some of the silos that we have constructed and the artificial bounds on what constitutes our curricula?

World War II showed us the importance of operations because logistics was key to winning a war. In the same way, do we need to rethink our curricula? Pandemics, systemic racism, and climate crises are complex systems that touch every aspect of human and planetary behaviorwork, transportation, education, shopping, leisure, manufacturing, health care, waste disposal, and others. These interlocking systems are far bigger and more complicated than organizations. They become "wicked" problems that defy simple solutions. Science, psychology, sociology, and economics become inseparable. The stakes rise: winning and losing become not just about financial accounts but about lives. Time frames change, too. While we mark time in years, months, weeks, and days, to address systemic challenges we have to think and plan in terms of generations.

If we want to train business leaders who can lead through war and peace, perhaps we need to put greater emphasis on training them to appreciate the complex systems that drive pandemics, racial divides, and climate tipping points. They must be primed to locate and exploit strategic intervention points. They must be sensitive to the consequences of their decisions, which will affect far more than stock market returns. They will need steady moral compasses that will permit them to make difficult trade-offs. They need to be system leaders if they are to be wartime generals and then peacetime leaders.

The wartime history suggests that not all innovations will survive through peacetime. In some instances, perhaps they are no longer needed; in other cases, the power of tradition might force a partial reversion to the status quo. But clearly, wartime-be it a military confrontation, the COVID pandemic, a racial divide, or the threat of climate destruction-creates the opportunity for innovation, some of which can be lasting.

Who decides? Decision making in peace and war. Academic decision making is typically highly consultative, with academic democracy held up as the norm. Long, protracted debates are cherished and decision 
making is slow. Faculty deliberation was the norm in the 1940s, too. As HBS went into World War II, Donham, the long-serving and soon-todepart dean, and David, his successor, made key decisions, but in different ways. Prewar, the faculty had appropriately played a huge role in the decision making of the school. The fundamental economics of the school, to quote Donham, was to "make money on the first year and lose it on the second year" of the MBA program. ${ }^{47}$ In 1941, Donham proposed a oneyear alternative program, in effect enrolling a larger MBA class of which some would complete two years and receive the MBA degree, while others would finish at the end of the first year with a bachelor of commerce degree. The proposal was rejected by the faculty but was ultimately refashioned as the Industrial Administrator program, a twelvemonth wartime program.

Yet, in wartime, decision-making dynamics changed. In May 1942 Donham was "six weeks from retirement.... [He] apologized for having taken a series of unilateral actions without adequate faculty consultation, but said that the fluid circumstances necessitated this approach." ${ }^{48}$ In one amusing exchange, Donham informed a faculty member, "You are volunteering for the job [to work with the government]." 49 The highly deliberative, consultative process of peacetime was replaced with a temporary new model: more rapid, centralized, strategic decision making, granting others closer to the battlefront (classroom) the flexibility to make tactical decisions. Berkeley's Dean Grether seemed to adopt a similar directive approach during the war.

Donham's successor, David, had careers in both academia and business and "a persistent vision of the School and the University as both a meeting ground for adversaries and a crucible for new types of communication." ${ }^{50} \mathrm{He}$ pushed forward a number of programs including the rare, ground-breaking Trade Union Fellowship Program in September 1942, which brought adversaries from business and labor to the school. While Donham's twenty-three years of service as dean may have afforded him greater ability to act unilaterally, David had to work with the faculty, especially as the war wound down, "to develop a postwar conception of the School. . . and help build consensus for that conception." 51

What does this say for the role of academic leadership as we enter this war against a pandemic and then identify our role in building a longer-term peace? In the short term, we may need to make bold and

\footnotetext{
${ }^{47}$ Cruikshank, Delicate Experiment, 211.

${ }^{48}$ Cruikshank, 223.

${ }^{49}$ Cruikshank, 226.

${ }^{50}$ Cruikshank, 268.

${ }^{51}$ Cruikshank, 225.
} 
hard strategic choices, sometimes quickly. The hardest choices will not be whether to go online, but rather more existential ones. Do we need to completely alter what and whom we teach? Does it make sense to continue to run the school at all? According to the Financial Times, more than eighty business school deanships are open at this time, and the candidates with the most desirable attributes are people who are adept at philanthropy and can boost rankings, primarily through enhancing alumni salaries, while delivering excellent education and research. Yet as we transition into wartime and then more complicated peace building, who should lead these schools? What is the appropriate faculty governance model? These are both uncomfortable questions, which are only relevant if we accept that we are indeed in a new phase.

Purpose both constrains and liberates. Whatever it takes. In the spirit of a conflict-of-interest disclosure, I confess that I know one of these schools far better than the other four. When I first arrived on the Soldiers Field Road campus in the early 1980s, nearly four decades after World War II, some of the remaining physical reminders of that era caught my attention. The glass library ceiling was still blacked out, just as it had been to make the building less visible to potential bombers. In the bowels of the tunnel system below the campus was a long narrow room that once served as a rifle range. On a sunlit and sometimes overheated corridor sat a group of emeritus professors lionized by the generation that followed them for having led the school through this difficult time. Even today, while renovations worth hundreds of millions of dollars have transformed the campus, some of the legacy of World War II remains under the polished cherry finishes, leather chairs, and perfect audiovisual systems.

All five of the schools-Wharton, Haas, Tuck, Chicago, and HBS-are considered among the top in our field, even though they took different approaches during World War II. Looking across all five, the war years were often instrumental to forging their post-war modern business identities. In some instances, schools created peacetime business schools and MBA programs in the middle of the war. Some new collaborations were created and experiments like Chicago's EMBA program flourished. What strikes me as being different about the fifth case study was not only that the modern school recognizes a huge debt to World War II, but also that it forged a modern business school in a very different way: it stopped being a business school. The wartime hiatus, where no MBAs came to campus, helped to define the HBS model for the postwar business school. This is not because wartime looked like peacetime, although the transition to winning the peace did indeed position business schools for the prosperity of the next decades. Rather, I would contend 


\section{Training Leaders to Win Wars and Forge Peace / 831}

that the adoption of a collective mission liberated the school to do whatever it took to win, including rejecting tradition and history.

Without a clear mission or purpose, organizations are constrained by history and tradition, by external metrics such as rankings or stock price performance, or by the whims of a leader. A clarion sense of purpose allows us to reject these forces. "Whatever it takes" is a license to experiment, to break rules, to innovate, to fail, to violate norms. At Harvard, this license was most forcefully seen in February 1945. The Allies were winning the war, but it was not yet over. The German surrender would not take place until May 8, the bombing of Hiroshima and Nagasaki on August 6 and 9, and the surrender of Japan on August 15. Yet, in February 1945, the HBS faculty considered the "Clean Sweep Resolution," which resulted in a unanimous vote to rescind all previous authorizations of courses. The faculty voted that they would not return to their prewar ways but would determine the future from that day forward. It is nearly impossible to imagine this vote in peacetime.

The wartime experiences surely granted this license, but it was neither free nor permanent. They (and we) still have to protect academic freedom, to make sure students are prepared for their futures, to break even or better, and to raise funds for important capital projects. When World War II was over, traditional forces slowly reclaimed their role, like ivy growing up the side of a New England building. Trade unionists left Soldiers Field in the late 1940s, as did women and young people. Some of the research and teaching innovations faded, but the core innovations that persisted defined modern business education.

Similarly, we may find that the experiences of battling an epidemic and economic meltdown, racial injustice, and a climate crisis provide us with the latitude to reject tradition and inertia as guiding principles. Put another way, peacetime and traditional academic practices nurture individual innovation; wartime and the adoption of collaborative notions of purpose permit wholesale institutional innovation.

\section{Conclusion and Discussion: Where Does This Leave Us Today?}

The experiences of leaders who ran business schools in the 1940 s seem, at one level, completely disconnected from our own. We are natives of the Fourth Industrial Revolution, not the early Third Industrial Revolution of the 1940 . We live in a globally connected society, despite increasing nationalism. Our research is much more scientific than the work done by business school academics in the 1940s. At some level, the landscape of business education is barely recognizable.

Or is it? The core courses we teach, or at least the titles of the courses, would be recognizable to our predecessors. The university challenges 
faced by our predecessors in the 1940 are surely still present today at many schools. Our teaching methods, apart from online courses, would look remarkably similar. Many of the questions we study have been studied before. And those looking from the 1940s would certainly recognize the twin senses of anxiety and responsibility we are facing. They too found themselves in a war that they neither started nor were prepared for. While war was waged elsewhere, it was possible at home to hunker down, to use the time to advance long-term agendas, to carry on with military activities alongside traditional ones-or to use the crisis to drive inconceivable and perhaps unplanned change.

What can we learn from these five very different reactions to global crisis? Five case studies do not permit a full analysis of why different schools pursued different strategies-or of their implications. But if the business school leaders from generations ago could speak to us, perhaps they might share the five lessons here:

It is normal to resist a crisis, but ultimately you have to own it if you want to use it to drive change. Whether isolationists or hawks, leaders could not ignore World War II, just as we cannot wish away COVID-19, systemic racism, widening inequality, or a climate emergency. However, if you are going to use it to bring about changewhether long-sought-after changes like those at Berkeley or the more emergent change that we see at Chicago and at Harvard, you must fully embrace the crisis.

Be clear about your mission or purpose, but flexible enough to adjust it as times change. In the case of Chicago, the primacy of the scholarly experience was a constant, even as the school created a new program for middle-aged managers. At HBS, there was a marked shift from the status quo to winning a war to winning a peace, with each redefined purpose leading to new action.

You are going to have to innovate. It is trite to say that necessity is the mother of invention, but not all people and institutions embrace innovation. Some examples, like Wharton's, demonstrate a strategy of maintaining diminished but still complete versions of their peacetime activities-in essence, waiting out the war. A few others showed the ability to simultaneously innovate while maintaining the status quo. Harvard's example is different in that it turned all of its attention to the war.

Decision making will change, perhaps for a while. These stories are ones of leadership. The transformation of Berkeley into a college, the 
creation of the University of Chicago's refugee scholar program, and Harvard's full shutting of all of its programs were products of strong leadership. This is not to say that these were executive decisions, but they were made by strong leaders, sometimes fighting literally the last war.

And finally, take advantage of the liberty of having a clear purpose to temper history and tradition. Change in academia can be tortuously slow and painful. For successful schools with long traditions and history, it can be even more difficult. The HBS example, in particular, shows that purpose, when it is authentic, can trump history and tradition and open up the possibilities for substantial change. And while all of these schools ultimately are recognized as some of the best in the world, Harvard's postwar edge probably flowed from its willingness to embrace massive change during the war.

What might our predecessors say to us? In World War II, approximately 418,500 Americans and 450,700 people from Great Britainmy home and host countries, respectively-perished, and many more from the Soviet Union, China, India, Germany, Poland, and Japan. ${ }^{52}$ As 2020 ends, COVID-19 fatalities in these two countries-after less than a year-are over 335,000 and 71,000 respectively-and rising materially each time I revise this article. 53 Then and now, mounting death tolls, the battle for human liberty and freedom, painful rifts between countries, and the need to forge a lasting peace call for action. If they could speak, perhaps our predecessors would assure us that we will get through this but exhort us to do whatever it takes. History will remember if we rise to the challenge.

PETER TUFANO is the Peter Moores Dean, Said Business School at the University of Oxford as well as a Professor Emeritus at Harvard Business School. As a financial economist, he studies household finance and financial innovation; as a business school leader, he writes about innovation in education required to address systemic challenges.

\footnotetext{
52 "Research Starters: Worldwide Deaths in World War II," National WWII Museum website, accessed 3 Dec. 2020, https://www.nationalww2museum.org/students-teachers/ student-resources/research-starters/research-starters-worldwide-deaths-world-war.

53 "Mortality Analyses," Coronavirus Research Center, Johns Hopkins University \& Medicine, accessed 30 Dec. 2020, https://coronavirus.jhu.edu/data/mortality.
} 